\title{
Perceptions, Fast Food Consumption and Eating Habits Among Students Belonging to the Allied Health Sciences
}

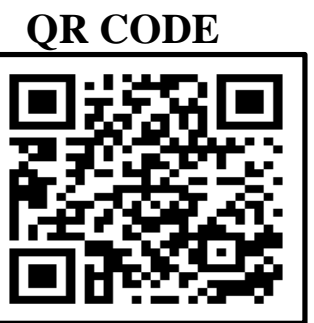

\section{REENA R. PRASAD', HUKAM CHAND*2, MOHD. ZAID³}

INTRODUCTION: The present generation is the most frequently targeted consumer for the fast food marketers and this can lead to various health related disorders in them.

AIM: To assess the perceptions, fast food consumption and eating habits among students belonging to the allied health sciences in various corners of India

MATERIALS AND METHOD: The study was an online, questionnaire based, cross-sectional study. The questionnaire was in English language, was pre-tested on 50 students and validated accordingly. The questionnaire was based on a 5-point Likert-type scale [(1) strongly disagree, (2) disagree, (3) neutral, (4) agree, and (5) Strongly agree]; had 19 questions and required approximately four minutes for completion. Data was analysed using SPSS version 21.0 and the student's t-test and multiple logistic regression was applied keeping the p value as 0.05 .

RESULTS: The study comprised of 1020 complete responses; out which males formed a majority (52.3\%) and most students belonged to the 2nd year of their study (49.1). High mean \pm SD scores pertaining to perception were obtained in four questions. While assessing the eating habits, high mean \pm SD scores were obtained in three questions. Multiple logistic regression based on gender revealed that females has a significant difference on both perception (0.01) and consumption(p-0.03) habits in relation to fast food as compared to males, while the year of study was significantly associated with the food consumption habits ( $\mathrm{p}=0.01)$ of the students. CONCLUSION: Universities and institutions need to educate and motivate students on the importance of healthy eating to reduce the burden of disease among such students.

\section{INTRODUCTION}

As a student enters a university/institution, there are certain changes in his/her living arrangement (which includes living in hostels, PG homes, etc) that results in a change in various factors, including their food choices and with their new found "freedom", they tend to prefer eating "fast foods".,

The term, "fast food" typically refers to food preparations that are prepared quickly, mostly purchased through self-service which is made from pre-cooked ingredients, and is served in a packaged form for the customer to take-away. ${ }^{3}$ The present generation is the most frequently targeted consumer for the fast food marketers and are flocked by students and children frequently. Infact, most students prefer eating junk food as compared to home cooked meals. ${ }^{4}$

As these students are given a monthly allowance, the overall competition among various food franchises to lower their prices by providing special offers and discounts makes it appealing and affordable to these students. 5 Due to the increased costs of living, and preference to dedicate their after college hours towards social interactions, sports and studying, students save time by ordering fast food. However, the intake of fast food among these students also contributes to various lifestyle related diseases such as eating behaviours, rising obesity rates, insulin resistance \& development of type 2 diabetes, hypertension and dyslipidemia. ${ }^{5}$

Due to the hidden dangers of fast food consumption to one's health, the present study was designed to explore and document the perceptions, fast food consumption and eating habits among students belonging to the allied health sciences and use the data to further chalk out intervention programs, if required.

\section{MATERIALS AND METHODS}

The present study was designed as descriptive crosssectional study which was conducted online from $10^{\text {th }}$ October, 2019 to $10^{\text {th }}$ January, 2020 after taking prior approval from the Institutional Review Board. The questionnaire was adopted from Abraham $\mathrm{S}$ et al. ${ }^{6}$ and later modified as per the present needs of the study. The questionnaire was in English language, was pretested on 50 students and validated accordingly as a part of the pilot study (Cronbach's $\alpha=0.87$ ). The questionnaire was based on a 5-point Likert-type scale. The scale options were (1) strongly disagree, (2) disagree, (3) neutral, (4) agree, and (5) Strongly agree. The questionnaire has a total of 19 questions and required approximately four minutes for completion.

Data was collected through convenience sampling and the questionnaire was distributed as a link on various 
social media sites and WhatsApp. Upon clicking the link, the participant was informed about the study objectives and instructed that the study meant is for college students belonging to the allied health sciences (Nursing, Physiotherapy, Homeopathy, Yoga, Unani and Siddha) based in India only and consent was obtained before initiating the survey. Participation in the study was purely voluntary and no personal details were collected from the participants. On the basis of the results obtained during the pilot study, the minimum sample required for the study was calculated as 349. All the participants were students aged 17 years or older.

Data was analysed using SPSS version 21.0 and the student's t-test and multiple logistic regression was applied keeping the p value as 0.05 .

\section{RESULTS}

Table 1 depicts the demographic details of the study population. There were a total of 1020 complete responses obtained, out which males formed a majority (52.3\%). Most students belonged to the $2^{\text {nd }}$ year of their study (49.1) and the least belonged to the $3^{\text {rd }}$ year of study (18.6\%).

\begin{tabular}{|c|c|}
\hline VARIABLE & $\mathbf{n}, \%$ \\
\hline $\begin{array}{c}\text { Males } \\
\text { Females }\end{array}$ & $\begin{array}{l}534(52.3) \\
486(47 \cdot 7)\end{array}$ \\
\hline $\begin{array}{c}\text { Year of study } \\
1^{\text {st }} \text { Year } \\
2^{\text {nd }} \text { Year } \\
3^{\text {rd }} \text { year and above }\end{array}$ & $\begin{array}{l}329(32.3) \\
501(49.1) \\
190(18.6)\end{array}$ \\
\hline
\end{tabular}

Table 1. Demographic details of the study population

Perceptions regarding fast food consumption among the study population is depicted in table 2 . High mean \pm SD scores (above 3.5) were obtained in the questions "Fast food consumption can lead to obesity"(3.9 \pm 1.33 ), "Home cooked meals provide me with a balanced diet"(3.5 \pm 0.17$)$, "Home-made meals are healthier than fast food meals." $(4.2 \pm 0,43)$, "It is easier to make fast food as compared to home-cooked meals" (4.5 \pm 0.33 , $\mathrm{p}={\left.\mathrm{O} .01^{*}\right)}^{*}$ and "Fast food does not affect my mental physical and spiritual well-being"(3.9 \pm 0.55$)$. Significant differences were also obtained in the questions "Diabetes and hypertension is a consequence of our eating habits." (2.6 $\pm 2.33, \mathrm{p}=0.05)$ and "I am concerned about my calorie intake while eating at fast food joints" (1.9 $\pm 1.99, \mathrm{p}=0.01)$.

High mean \pm SD scores (above 3.5) regarding food consumption were obtained in the questions "Busy days lead to increased consumption of fast food"(3.9 $\pm 0.52, \quad \mathrm{p}=0.04)$, "I usually order/have a sweetened beverage along with fast food"(4.1 \pm 0.32$)$, and "I tend to order fast food when I am stressed"(3.8 \pm 0.43$)$. Significant differences was also obtained when the students responded to the question "I share my fast food with friends" $(2.7 \pm 0.78, \mathrm{p}=0.04)$ and is depicted in table 3 .

The results based on the multiple logistic regression are depicted in table 4. Analysis based on gender revealed that females has a significant difference on both perception (o.o1) and consumption(p-0.03) habits in relation to fast food as compared to males, while the year of study was significantly associated with the food consumption habits $(\mathrm{p}=\mathrm{o.01})$ of the students.

\section{DISCUSSION}

Based on the results of the present study, it was observed that students perceived fast food as a viable option as compared to home cooked meals and their habits included increased fast-food consumption, especially on busy and stressful days. The present study had more respondents belonging to the second year of their course and this can be attributed to the fact that as the course progresses, students get busy with their academic work preparing for their final examinations and hence, show lesser participation in such studies.

It was revealed that females were more concerned and conscious regarding fast food consumption in comparison to their male counterparts and these findings are in agreement to studies conducted by Mahajan SA et al. (2020) 7 and Bipasha MS et al. (2013). ${ }^{8}$

Beverage intake along with fast food was reported by approximately $83 \%$ of the respondents $(4.1 \pm 0.32)$ and the results were in agreement to various authors who documented unhealthy eating patterns along with a high level of beverage (soft drinks) consumption..$^{9,10}$ In addition, Deliens $\mathrm{T}$ et al. (2015) reported a massive consumption of $423.6 \pm 445.2 \mathrm{ml}$ of soft and energy drinks among Belgian university students."

The responses of the students in the present study 


\begin{tabular}{|c|c|c|c|}
\hline & MEAN & SD & P VALUE \\
\hline $\begin{array}{c}\text { Fast food consumption } \\
\text { can lead to obesity }\end{array}$ & 3.9 & 1.33 & NS \\
\hline $\begin{array}{l}\text { I am happy eating home } \\
\text { made food }\end{array}$ & 2.3 & 1.6 & NS \\
\hline $\begin{array}{c}\text { Home cooked meals } \\
\text { provide me with a } \\
\text { balanced diet }\end{array}$ & 3.5 & 0.17 & NS \\
\hline $\begin{array}{c}\text { Home-made meals are } \\
\text { healthier than fast food } \\
\text { meals. }\end{array}$ & 4.2 & 0.43 & NS \\
\hline $\begin{array}{c}\text { Diabetes and } \\
\text { hypertension is a } \\
\text { consequence of our eating } \\
\text { habits. }\end{array}$ & 2.6 & 2.33 & $0.05^{*}$ \\
\hline $\begin{array}{l}\text { I am concerned about my } \\
\text { calorie intake while } \\
\text { eating at fast food joints. }\end{array}$ & 1.9 & 1.99 & $0.03^{*}$ \\
\hline $\begin{array}{l}\text { It is easier to make fast } \\
\text { food as compared to } \\
\text { home-cooked meals }\end{array}$ & 4.5 & 0.33 & $0.01^{*}$ \\
\hline $\begin{array}{l}\text { I find fast food more } \\
\text { appealing as compared to } \\
\text { home cooked meals. }\end{array}$ & 3.2 & 0.76 & NS \\
\hline $\begin{array}{c}\text { Eating fast food has the } \\
\text { same caloric value as } \\
\text { eating at home. }\end{array}$ & $3 \cdot 3$ & 0.63 & NS \\
\hline $\begin{array}{l}\text { Fast food does not affect } \\
\text { my mental physical and } \\
\text { spiritual well being }\end{array}$ & 3.9 & 0.55 & NS \\
\hline
\end{tabular}

Table 2. Perceptions regarding fast food consumption among the study population (NS: Non-Significant)

stating that they were conscious of the calories they consume while eating at fast food restaurants(1.9 \pm 1.99$)$ as well as agreeing to the fact that fast food consumption can lead to obesity $(3.9 \pm 1.33)$ is in agreement to the results of the various authors where students reported that increased calorie consumption can lead to weight gain in individuals consuming fast food. ${ }^{12,13}$ A total of $3.2 \pm 0.76$ students found fast food more appealing as compared to home cooked meals, and this statement is in disagreement to Shah $\mathrm{T}$ et al. (2014) where participants did not find fast food to be more appealing. ${ }^{14}$

The limitations of the study could potentially include under and over-reporting of the questions by the respondents and to decrease the same, the researchers did not collect any personal data from the students, due to which, the results of the present study can be generalized.

\section{CONCLUSION}

It is recommended that universities and institutions need to educate and motivate students on the importance of healthy eating so that the burden of obesity and health related disorders among university going students can be reduced.

\section{REFERENCES}

1. Brevard PB, Ricketts CD. Residence of college students affects dietary intake, physical activity, and serum lipid levels. J Am Diet Assoc. 1996, 96: 35-8. https://doi.org/10.1016/Sooo2-8223(96)ooo11-9.

2. Kremmyda LS, Papadaki A, Hondros G, Kapsokefalou M, Scott JA: Differentiating between the effect of rapid dietary acculturation and the effect of living away from home for the first time, on the diets of Greek students studying in Glasgow. Appetite. 2008, 50:455-63. https://doi.org/10.1016/j.appet.2007.09.014. 3. Alfaris NA, Al-Tamimi JZ, Al-Jobair MO, Al- 


\begin{tabular}{|c|c|c|c|}
\hline & MEAN & SD & N VALUE \\
\hline $\begin{array}{c}\text { I frequently order fast } \\
\text { food while with friends }\end{array}$ & 3.2 & 0.71 & NS \\
\hline $\begin{array}{c}\text { I order fast food more } \\
\text { than twice in a week }\end{array}$ & 2.9 & 1.1 & $0.04^{*}$ \\
\hline $\begin{array}{c}\text { Busy days lead to } \\
\text { increased consumption } \\
\text { of fast food }\end{array}$ & 3.9 & 0.52 & NS \\
\hline $\begin{array}{c}\text { I usually order/have a } \\
\text { sweetened beverage } \\
\text { along with fast food }\end{array}$ & 4.1 & 0.32 & NS \\
\hline $\begin{array}{c}\text { I order healthier, } \\
\text { vegetable based fast } \\
\text { food (like salads etc) }\end{array}$ & 1.3 & 0.21 & NS \\
\hline $\begin{array}{c}\text { I order extra cheese } \\
\text { with my order }\end{array}$ & 3.3 & 0.43 & $0.02^{*}$ \\
\hline $\begin{array}{c}\text { I chew my fast food } \\
\text { properly. }\end{array}$ & 1.1 & 2.5 & NS \\
\hline $\begin{array}{c}\text { I share my fast food } \\
\text { with friends }\end{array}$ & 2.7 & 0.78 & 0.43 \\
\hline $\begin{array}{c}\text { I tend to order fast food } \\
\text { when I am stressed }\end{array}$ & 3.8 & & \\
\hline
\end{tabular}

Table 3. Food consumption habits among the study population (NS: Non-Significant)

\begin{tabular}{|c|c|c|}
\multicolumn{2}{|c|}{$\begin{array}{c}\text { PERCEPTIONS } \\
\text { REGARDING } \\
\text { FAST FOOD }\end{array}$} & $\begin{array}{c}\text { FOOD } \\
\text { CONSUMPTION } \\
\text { HABITS }\end{array}$ \\
\hline Gender & $0.01^{*}$ & $0.03^{*}$ \\
\hline $\begin{array}{c}\text { Year of } \\
\text { study }\end{array}$ & NS & $0.01^{*}$ \\
\hline
\end{tabular}

Table 4. Multiple Logistic Regression based on gender and year of study. (NS: NonSignificant)

Shwaiyat, MN. Trends of Fast Food Consumption Among Adolescent and Young Adult Saudi Girls Living In Riyadh. Food Nutr Res. 2015;59:26488. 10.3402/fnr.v59.26488. eCollection 2015.

4. Sogari G, Velez-Argumedo C, Gómez MI, Mora C. College Students and Eating Habits: A Study Using An Ecological Model for Healthy Behavior. Nutrients. 2018;10(12):1823. https://doi.org/10.339o/nu10121823 5. Abdullah NN, Mokhtar MM, Bakar MHA, Al-Kubaisy W. Trend on Fast Food Consumption in Relation to Obesity among Selangor Urban Community. Procedia -Social and Behavioral Sciences 2015; 202:505-13. https://doi.org/10.1016/j.sbspro.2015.08.189

6. Abraham S, Martinez M, Salas G, et al. College student's perception of risk factors related to fast food consumption and their eating. habits. J Nutr Hum Health. 2018;2(1):18-21.

7. Mahajan SA, Gothankar JS. Fast food consumption pattern amongst undergraduates of various disciplines of private colleges in Pune. Int J Community Med Public Health. 2020;7:505-11.

8. Bipasha MS, Goon S. Fast food preferences and food habits among students of private universities in Bangladesh. South East Asia J Public Health. 2013;3(1):61-4

9. Yarmohammadi P, Sharifirad GR, Azadbakht L, Yarmohammadi P, Rahaei Z, Bahrevar V, et al. The Association between Socio-Demographic Charactristics and Fast Food Consumption within High School Students in Isfahan, Iran. J Community Health Res. 2015;4(3):194-202.

10. Jaworowska A, Blackham I, Davies I, et al. Nutritional challenges and health implications of takeaway and fas food. Nutr Rev. 2013;71:310-8.

11. Deliens T, Clarys P, Bourdeaudhuij ID, Deforche B. Correlates of University Students' Soft and Energy Drink Consumption According to Gender and Residency. Nutrients. 2015;7(8): 6550-6. 10.3390/nu7085298

12. Dingman D, Schulz M, Wyrick D, et al. Factors related to the number of fast food meals obtained by college meal plan students. J Am Coll Health. 2014;62:562-69.

13. De Vogli R, Kouvonen A, Gimeno D. Globesization: Ecological evidence on the relationship between fast food outlets and obesity among 26 advanced economies. Critical Public Health. 2011;21:395-02. 
14. Shah T, Purohit G, Pillai NS, et al. Assessment of obesity, overweight and its association with the fast food consumption in medical students. J Clin Diagn Res. 2014;8:CCo5-CCo7.

Cite this article as:

Prasad RR, Chand H, Zaid M. Perceptions, Fast Food Consumption and Eating Habits

Among Students Belonging to the Allied Health Sciences. Int Healthc Res J. 2021;5(2)OR7-

OR11. https://doi.org/10.26440/IHRJ/0502.05424

AUTHOR AFFILIATIONS: (*Corresponding Author)

1. B.Sc (Nursing), Independent Researcher \& Consultant, Kesroli, District Alwar, Rajasthan India

2. BPT, Independent Researcher \& Consultant, Kesroli, District Alwar, Rajasthan India

3. M.Sc (Food Science \& Nutrition), Independent Researcher \& Consultant, Kathmandu, Nepal

Source of support: Nil, Conflict of interest: None declared 